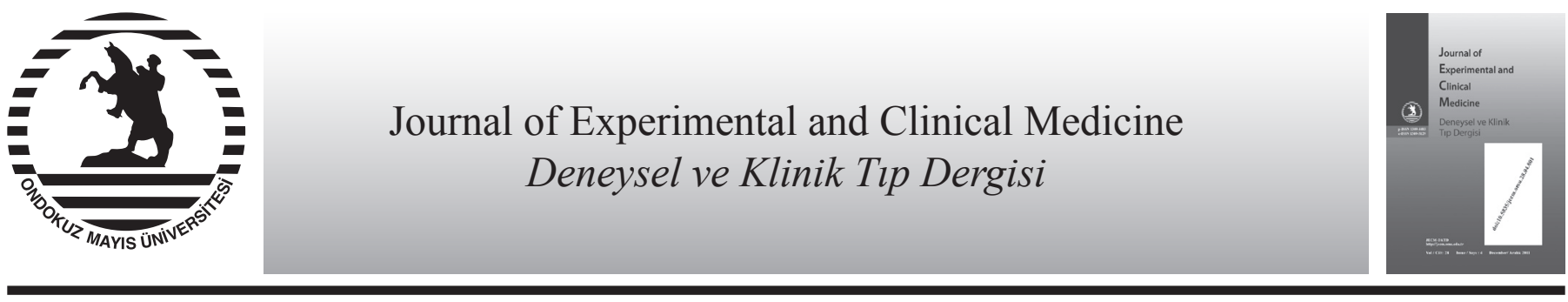

Derleme / Review

doi: $10.5835 /$ jecm.omu.28.04.002

\title{
Brusellozda akciğer tutulumu
}

Pulmonary involvement in brucellosis

Özgür Günal ${ }^{\text {a* }}$, Serdar Berk ${ }^{\mathrm{b}}$, Hüseyin Şener Barut ${ }^{\mathrm{a}}$

${ }^{a}$ Gaziosmanpaşa Üniversitesi Tıp Fakültesi Enfeksiyon Hastalıkları ve Klinik Mikrobiyoloji Anabilim Dall, Tokat

${ }^{b}$ Cumhuriyet Üniversitesi, Tıp Fakültesi, Göğ̈̈s Hastalıklarl ve Tüberküloz Anabilim Dalı, Sivas

\begin{tabular}{|c|c|}
\hline MAKALE BİLGILERİ & ÖZET \\
\hline Makale geçmişi & Brusellozis, hala ciddi bir enfeksiyon hastalığı olup insanlar için önemli bir morbidite \\
\hline Geliş $\quad 06 / 01 / 2011$ & nedeni olmayı sürdürmektedir. Başta Akdeniz ülkeleri olmak üzere dünyanın hemen her \\
\hline $26 / 03 / 2011$ & yerinde ve her yaşta görülebilir. Hastalarda kas ve eklem tutulumu dışında, pnömoni, am- \\
\hline $\begin{array}{l}\text { * Yazışma Adresi: } \\
\text { Özgür Günal } \\
\text { Gaziosmanpaşa Üniversitesi }\end{array}$ & $\begin{array}{l}\text { gibi farklı klinik tablolarda görülebilmektedir. Bu makalede literatürde daha çok olgu } \\
\text { sunumu olarak, nadiren de klinik araştırma şeklinde yayınlanmış olan pulmoner bruselloz } \\
\text { vakaları gözden geçirilmiş ve değerlendirilmiştir. } \\
\text { J. Exp. Clin. Med., 2011; 28:128-131 }\end{array}$ \\
\hline
\end{tabular}

Tip Fakültesi

Enfeksiyon Hastalıkları ve

Klinik Mikrobiyoloji Anabilim Dalı.

Merkez/Tokat

E-posta: ozgurgop@yahoo.com

\section{Anahtar Kelimeler:}

Zoonoz

Brusellozis

Inhalasyon

Akciğer tutulumu

Pnömoni

Mortalite

Keywords:

Zoonosis

Brucellosis

Inhalation

Pulmonary involvement

Pneumonia

Mortality

\begin{abstract}
Brucellosis is still a serious infectious disease that remains being an important causes of morbidity for humans. It can be seen at all age and almost everywhere in world as well as in the Mediterranean countries. Besides the muscle and joint involvement, it may appear different clinical tables such as pneumonia, empyema, lung abscess, prostatitis, endocarditis, meningoencephalitis or brain abscess. In this article pulmonary brucellosis cases which were published rarely as a clinical resarch and mostly as a case report in literature were observed and evaluated.

J. Exp. Clin. Med., 2011; 28:128-131
\end{abstract}

C 2011 OMÜ Tüm hakları saklıdır

\section{Giriş}

Brusellozis dünyanın pek çok bölgesinde önemli bir sağlık problemi olmaya devam etmektedir. Her y1l, bu hastalık binlerce insanda kronik hastalık tablosu oluşturmakta ve nadiren ölümle sonuçlanmaktadır (Akbulut ve ark., 2005). Ülkemizde sağlıklı popülasyonda bruselloz seropozitifliği \%2-8 arasında gözlenirken, risk gruplarında seropozitiflik \%2-25 arasında değişen oranlarda gözlenmektedir (Güneş ve ark., 2009).

Etken, gram negatif, sporsuz, hareketsiz, küçük kokoba- sil yapısında bakterilerdir. Islak ve nemli ortamlarda kolay ürerler, bu yüzden çiğ süt ve süt ürünlerinde uzun süre kalabilirler. Kaynatmakla ve pastörizasyon ile inaktive olurlar (Alptekin ve Bilgiç, 2003). Tüm dünyada brusellozis vakalarında en sık izole edilen alt tür B.melitensis'tir. En sık rastlanan rezervuarları ise koyun ve keçilerdir. B.abortus özellikle sığırlarda bulunurken, B.suis yerel olarak görülür ve yaban domuzlarında sık olarak gözlenir. B.canis pek çok ülkede köpeklerde gözlenir ancak insan enfeksiyonu nadirdir (Young, 2010). 
Brusellozis primer olarak hayvanlarda bulunur insanlara bulaşma, pastörize edilmemiş süt ve süt ürünlerinin tüketimi, infekte hayvanların sekresyonlarının bütünlüğü bozulmuş cilt ile direkt temas1, infekte aerosollerin inhalasyonu veya konjunktivaya inokulasyonu ile olmaktadır (Yüce ve Çavuş, 2006). Hastalık kemik, eklem, kalp, akciğer ve santral sinir sistemi gibi organları tutabilmektedir (Al-Awadh ve ark., 2005).

\section{Klinik}

Bruselloz ateş, gece terlemeleri, iştahsızlık, kilo kaybı, halsizlik, şiddetli baş ağrısı ve poliartralji gibi nonspesifik semptomlarla karakterize bir hastalıktır. Fiziksel bulgular hastalık süresine bağlı olup hepatosplenomegali, lenfadenopati, spondilit ve artriti içerebilir (Colmenero ve ark., 1991; Kanterewicz ve ark., 1994). Gürsoy ve ark. (2008)'nın yaptıkları çalışmada başlıca klinik semptomlar ateş, artralji, terleme ve halsizlik iken, ateş $(\% 61,2)$, lenfadenopati $(\% 11,4)$, splenomegali $(\% 10,7)$, hepatomegali $(\% 8,6)$ ve artrit $(\% 5,7)$ en sık saptanan bulgular olmuştur. Aygen ve ark. (2002)'nın 480 bruselloz olgusunda yaptıkları çalışmada en sık görülen klinik semptomlar halsizlik, terleme, artralji, ateş, sırt ağrısı ve miyalji olurken, en sık görülen klinik bulgular ateş, hepatomegali, osteoartiküler tutulum, splenomegali ve nörolojik tutulum bulguları olmuştur. Bu çalışmada bir hastada pnömoni saptanmıştır. Asemptomatik veya subklinik bruselloz, genellikle çiftçiler, mezbahane çalışanları ve veterinerlerde gözlenir. Hastada hastalığın semptom ve bulguları yoktur. Tanı pozitif seroloji ile konur (Doğanay ve Meşe, 2008). Hastalarda kas ve eklem tutulumu dişında, pnömoni, ampiyem, akciğer apsesi, prostatit, endokardit, lenfositik meningoensefalit ve beyin apsesi gibi farklı klinik tablolarda görülebilmektedir (Corbel ve Beeching, 2010).

\section{Tanı}

Hastaların mutlaka brusellozisin endemik olduğu bölgelere seyahat etme, mikrobiyoloji laboratuarında çalışma, pastörize edilmemiş süt ve süt ürünü tüketme, hayvanlarla temas ve ailede bruselloz hastalığı öyküsü açısından sorgulanması gerekir (Corbel ve Beeching, 2010). Hastalarda laboratuar bulgusu olarak; lökositoz (özellikle fokal komplikasyonları olanlarda), lökopeni, trombositopeni ve anemi gözlenebilir (Franco ve ark., 2007). Eritrosit sedimentasyon hizı ve C-Reaktif protein'de genel olarak hafif-orta düzeyde artma ve karaciğer enzimlerinde orta düzeyde yükselme görülebilir (Bal ve ark., 2008).

Gürsoy ve ark. (2008)' nın çalışmasında en sık saptanan laboratuar bulguları C-reaktif protein yüksekliği, transaminaz yüksekliği, anemi ve lökositoz olmuştur. Brusellozun kesin tanısı kan, kemik iliği, doku biyopsisi ve BOS gibi örneklerden bakterinin izole edilmesi ile konulur. Kan ve kemik iliği kültürleri sıklıkla akut fazda pozitiftir. Kan kültürünün duyarlılığı \%15-70 aralığındadır. Kemik iliği kültürü, bakteri özellikle retiküloendotelyal sistemde yüksek konsantrasyonda olduğu için altın standart yöntemdir. Otomatize kan kültür sistemleri Brusella türlerinin saptanma sürelerini kısaltmaktadır (Alışkan, 2008).

Rose Bengal (RB) testi genellikle tarama testi olarak kullanılır ve pozitif sonuçların serum tüp aglütinasyon testi ile konfirme edilmesi gerekir (Franco ve ark., 2007). Standart Tüp Aglütinasyon testi (STA), insan brusellozunun doğrulanmasında en sık kullanılan serolojik yöntemdir. Klinik bul- gular varlığında serokonversiyonun ya da $\geq 1 / 160$ titrelerin saptanması hastalığın tanısında yol göstericidir. Klinik olarak kuvvetle şüpheli hastalarda seropozitifliğin saptanamamas1, enfeksiyonun çok erken dönemini, blokan (non agglutinating, incomplete) antikorların varlığını ya da prozon fenomeni (hasta serumunda antikor fazlalığı nedeniyle düşük suland1rımlarda aglütinasyonun görülmemesi)'ni düşündürmelidir (Alışkan, 2008).

Coombs' (anti-insan globulin) testi blokan antikorları ve prozon fenomenini ortadan kaldırarak aglütinasyon testinin duyarlılığını artıran bir yöntemdir (Alışkan, 2008). Enzim immün yöntemleri (ELISA), Brucella'ya özgü IgG, IgM ve IgA antikorlarının düzeyini belirleyen, klinik yorumu daha kolay olan ve STA testinde yalancı negatiflik/pozitifliklere neden olan faktörleri ortadan kaldıran bir yöntemdir (Alışkan, 2008). ELISA testinin daha basitleştirilmiş şekli olan Florosan polarizasyon immünoassey (FPA) ve immünokromatografik brusella IgM/IgG lateral akım yöntemi (LFA) hızlı tanı yöntemleri olarak kullanılmaktadır (Franco ve ark., 2007).

Araj ve ark. (2005)'nın yaptığı karşılaştırmalı bir çalışmada, RB ve STA yönteminin basit, güvenilir ve ucuz oldukları için akut bruselloz olgularında kullanılabileceği, kronik ve komplike olgularda bu yöntemlerin olguların \%7'sini kaçırabileceği ve dolayısıyla bu hastalarda ELISA yönteminin tercih edilebileceği vurgulanmıştır. Mert ve ark. (2003)'nın yaptığı çalışmada ise brusella tanısında standart tüp aglütinasyonunun çok spesifik ve sensitif bir test olduğu gösterilmiştir.

Tanıda indirek hemaglütinasyon testi, radyoaktif immüno deney (RIA) ve polimeraz zincir reaksiyonu (PCR) gibi yöntemlerde kullanılmaktadır (Topçu ve ark., 1996). Sağlık Bakanlığı'nın Bulaşıcı Hastalıkların İhbarı ve Bildirim Sistemi Standart Tanı, Sürveyans ve Laboraruvar Rehberi'inde Bruselloz doğrulayıcı tanısı olarak üç kriter belirlenmiştir. Bunlar; klinik örneklerden Brucella spp.'nin izolasyonu, daha önce tedavi almamış olguda, tek serum örneğinde STA ile antikor titresinin $>1 / 160$ olması ve en az iki hafta ara ile alınan çift serum örneğinde Brucella STA titresinin 4 kat artışıdır (TC Sağlık Bakanlığı, 2005).

\section{Pulmoner Bruselloz}

Bu bölümde literatürde daha çok olgu sunumu olarak, nadiren de klinik araştırma şeklinde yayınlanmış olan pulmoner bruselloz vakalarının gözden geçirilmesi ve değerlendirilmesi amaçlanmıştır.

Daha çok genç erişkinlerde görülen brusellozun bulaşma yollarından birisi de inhalasyon yolu olmasına rağmen akciğer tutulumu nadirdir. İnhalasyon yoluyla karşılaşma dişında bakteriyemi sonucunda da bakterinin akciğerlere ulaşması ile solunum sistemi bulguları görülebilir. Solunum sistemi bulguları akut veya kronik olabilir ve olguların \%15-25'inde görülür. Akciğer tutulumunda en sık görülen semptom genellikle nonproduktif öksürüktür (Dilmener, 1990; Batmaz ve ark., 2007).

Pappas ve ark. (2003) çok merkezli bir araştırmada bruselloz tanısı konan 450 hastanın 37'sinde $(\% 6,9)$ çeşitli şekillerde pulmoner tutulumun bulunduğunu bildirmişlerdir. $\mathrm{Bu}$ araştırmada pulmoner tutulum olan 37 hastanın yaş ortalamasının 53/yıl, kadın/erkek oranının 1/2 olduğu hastaların 35 'inde $(\% 94,5)$ ateş görülürken, 25 'inde $(\% 67,6)$ öksürük, 10'unda (\%27) balgam, 7'sinde (\%19) nefes darlığ 1 gibi solunumsal semptomların görüldüğü bildirilmiştir. 
Üç yüz yetmiş dokuz bruselloz hastasının değerlendirildiği başka bir çalışmada 87 hastada öksürük, nefes darlığı ve grip benzeri solunumsal semptomların görüldüğü, 23 hastada $(\% 6,3)$ anormal akciğer grafisi bulgularının olduğu bildirilmiştir (Mousa ve ark., 1988).

Ülkemizde yapılan geniş serili bir araştırmada 1028 bruselloz vakası retrospektif olarak incelenmiş, hastaların yaş ortalamasının 33,7 yıl olduğu, en sik klinik ve laboratuvar bulgularının ateş, artralji, CRP yüksekliği, en sık tutulumun oateoartiküler tutulum olduğu bildirilmiştir. Yine bu araştırmada vakaların \%2'sinde öksürük saptanmışken, 7 hastada $(\% 0,7)$ plörezi şeklinde pulmoner tutulum saptanmıştır (Buzgan ve ark., 2010). Bruselloz hastalarının \%1-16'sında akciğer grafisinde anomaliler görülebilir ancak bu anomaliler patognomonik değildir. Bu bulgular bronkopnömoni, interstisyel pnömoni, plevral effüzyon, apse, pulmoner noduller ve hiler, paratrakeal lenfadenopati şeklinde görülebilir. Genellikle subakut ve kronik brusellozda görülürler. Sıklıkla tedavi süresinin yetersizliğine bağlıdır. Lober pnömoni oldukça nadir görülmekte ve B. melitensis'in endemik olduğu bölgelerde atipik pnömoni olarak yanlış tanı alabilmektedir (Sanford, 1997).

Şekil 1'de kliniğimizde takip edilen pnömonik infiltrasyon ve plevral effüzyon şeklinde prezente olan 20 yaşında ki bruselloz hastasına ait toraks radyolojik görüntüleri gösteril miştir. Hastanın serolojik testleri ve kan kültürleri brucella yönünden pozitif bulunmuştur.

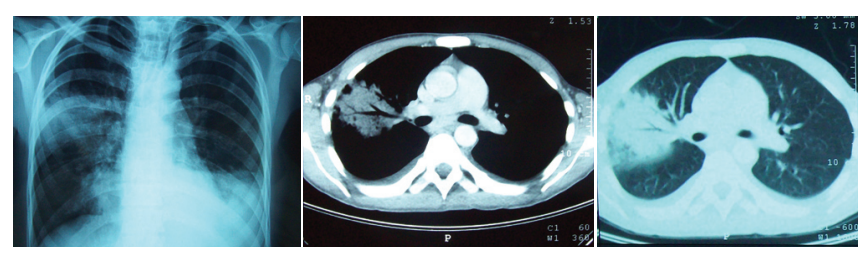

Şek. 1. Sağ üst lobda pnömoni ve bilateral minimal plörezi ile seyreden bir pulmoner bruselloz olgusunun direk grafi ve bilgisayarlı tomografi görüntüleri.

Otuz yedi pulmoner brusellozlu hastanın akciğer radyolojisinin değerlendirildiği bir çalışmada 15 hastada $(\% 40,5)$ interstisyel patern, 12 'sinde $(\% 32,4)$ lober pnömoni, 4'ünde $(\% 10,8)$ plevral effüzyon (ikisinde sol, birinde sağ hemitoraksta, birinde de bilateral), 4'ünde balpeteği görünümü, 2'sinde ise hiler lenfadenopati şeklinde tutulum saptanmıştır ( Pappas ve ark., 2003). Yüz on bruselloz hastasının prospektif izlendiği başka bir araştırmada 11 hastada (\%10) pulmoner tutulum saptanmıştır. Bu hastalarda klinik olarak öksürük, balgam, nefes darlığı semptomlarının olduğu, radyolojik olarak da parankimal nodul, lober pnömoni, paratrakeal lenfadenopati ve plevral effüzyon gibi pulmoner tutulumların olduğu saptanmıştır. Bruselloz tedavisi ile bu bulguların tamamen düzeldiği bildirilmiştir (Hatipoglu ve ark., 2005). Pulmoner bruselloz tanısında standart serolojik tetkiklerin yanı sıra balgam, bronş lavajı, plevral mai ve hatta pulmoner parankim biyopsisi örnekleri de kullanılabilir. Webb ve arkadaşları soliter pulmoner nodülü bulunan asemptomatik bir hastada torakotomi ile nodülde $\mathrm{B}$. suis izole etmişlerdir (Webb ve Thoroughman, 1966). Zengi ve ark. (2006)'da pulmoner tutulum gösteren bir olguda plevra mayisinde ve kanda B.melitensis izole etmiştir.

Özellikle hemorajik tipte plevral effüzyon, pulmoner bruselloziste çok daha nadir olarak görülmektedir. Papiris ve arkadaşlar, pH ve glukoz düzeyi düşük, Brucella melitensis için plevral sıvı kültürleri $(+)$ olan hemorajik effüzyonlu bir olgu yayınlamışlardır (Papiris ve ark., 1994).

\section{Tedavi}

Bruselloz tedavisinde doksisiklin, tetrasiklin, rifampisin, siprofloksasin, ofloksasin, trimetoprim-sulfametoksazol ve aminoglikozitlerden (örn: gentamisin, streptomisin) oluşan ikili veya üçlü kombinasyon tedavileri kullanılabilmektedir (Alp ve ark., 2006; Aydın ve ark., 2006). Dünya Sağlık Örgütü (WHO) Bruselloz'un oral tedavisinde; Doksisiklin 200 mg/gün ve Rifampisin 600-900 mg/gün kombine, oral/parenteral tedavide ise doksisiklin ile birlikte Streptomisin $15 \mathrm{mg} /$ kg/gün (ilk 2-3 hafta) kombinasyonlarının en az 6 hafta kullanılmasını önermektedir (Franco ve ark., 2007).

Standart bruselloz tedavisi genellikle pulmoner tutulumlu hastalar içinde yeterlidir. Bununla birlikte ampiyem, plevral kalınlaşma gibi komplikasyonların geliştiği durumlarda ek girişimsel tedaviler gerekebilir. Mili ve arkadaşları 39 yaşında erkek hastada ampiyem karakterindeki sağ plevral effüzyonda brucellanın ürediğini, doksisiklin+gentamisin tedavisi ile hastanın iyileştiğini bildirmişılerdir (Mili ve ark., 1993). Pnömoni ve parapnömonik effüzyon şeklinde pulmoner tutulum gösteren bir bruselloz vakasında hem plevral sıvida hem de kanda bruselloza yönelik serolojik testler pozitif saptanmış, hasta trimeroprim-sulfometaksazol, rifampisin ve streptomisin kombinasyonu ile başarılı şekilde tedavi edilmiştir (Peker ve ark., 2010). Al-Anazi ve ark., (2005) ise bruselloza bağlı hemorajik plevral effüzyon gelişen ve medikal tedaviye yanit vermeyen 37 yaşındaki bir hastaya dekortikasyon yaparak başarılı bir şekilde tedavi etmişlerdir. Bruselloz tedavisinde rifampisin kullanılmakla birlikte özellikle tanısı şüpheli vakalarda rifampisinin tüberküloz hastalığı ihtimaline karşı rezervde tutulması daha doğru bir yaklaşım olacaktır

\section{Prognoz}

Bruselloz insanlar için nadiren ölümcül seyreder, fakat şiddetli organ kullanım yetersizliklerine yol açabilir (Franco ve ark., 2007). Ülkemizde bruselloz, morbiditesi oldukça yüksek olmasına karşın mortalitesi çok düşük bir enfeksiyon hastalığıdır. Ülkemizde 1980 'li yıllarda mortalite oranı \%0,3 olarak verilirken, 1990'l1 y1llarda mortalite oran1 \%0,03'lere gerilemiştir (Sözen, 2002). 2001 yılında ülkemizde 15510 yeni vaka tespit edilmiş ve mortalite oranı $\% 0.03$ olarak saptanmıştır (TC Sağlık Bakanlığı, 2001). Park ve ark. (2007) 51 yaşında bir hastanın Toraks BT incelemesinde bilateral yaygın parankimal ve plevral nodüllerin eşlik ettiği plörezi olgusu bildirmişlerdir. Hastada etken olarak brusella abortus saptanmış ancak doksisiklin+ streptomisin tedavisine rağmen başta hepatit olmak üzere yaygın ekstrapulmoner tutulumları da bulunan hasta kurtarılamamıştır.

Brusella'ya maruz kalma sonrasında proflaksi yapılmasına yönelik bir kanıt yoktur. Ancak bir çok otorite enfekte aerosol teması sonrasında en az 6 hafta süreyle rifampisin + doksisiklin kullanılmasını önermektedir (Corbel ve Beeching, 2010). Pulmoner bruselloz ayırıcı tanıda en çok diğer bakteriyel pnömoniler ve akciğer tüberkülozu veya tüberküloz plörezi ile karışabilir. Literatürde pulmoner tüberkülozdan ayırt edilemeyen plevral kalınlaşma ve intrapulmoner infiltratların geliştiği 38 yaşında bir olgu da bildirilmiştir (Takahashi ve ark., 1996).

Sonuç olarak, multisitemik tutulum gösteren brusellozun nadiren de olsa özellikle pnömoni, plevral effüzyon şeklin- 
de pulmoner tutuluma neden olduğu, ülkemiz gibi hastalığın endemik görüldüğü bölgelerde muhtemel pulmoner tutulum ve komplikasyonlar yönünden hastaların titizlikle izlenmesi gerektiğini söyleyebiliriz.

\section{KAYNAKLAR}

Akbulut, H.H., Çelik, İ., Akbulut, A., Yüce, P., Kılıç, S.S., 2005. Serum neopterin levels in patients with brucellosis. J. Infection. 51, 281-286. Alışkan, H., 2008. Kültür ve serolojik yöntemlerin insan brusellozu tanısındaki değeri. Mikrobiyol. Bul. 42, 185-195.

Al-Awadh, R., Al-Anazi, S., Aziz, M., Fouda, A., 2005. Brucellosis: haemorrhagic pleural effusion. Med. Princ. Pract. 14, 118-120.

Alp, E., Koç, R.K., Durak, A.C., 2006. Doxycycline plus streptomycin versus ciprofloxacin plus rifampicin in spinal brucellosis. BMC Infect. Dis. 6, 72 .

Alptekin, N., Bilgiç, A., 2003. Brusellozis. Fiziksel Tip ve Rehabilitasyon. 3, 97-105.

Araj, G.F., Kattar, M.M., Fattouh, L.G., Bajakian, K.O., Kobeissi, S.A., 2005. Evaluation of the PANBIO Brucella immunoglobulin G (IgG) and IgM enzyme-linked immunosorbent assays for diagnosis of human brucellosis. Clin. Diagn. Lab. Immunol. 12, 1334-1335.

Aydın, G., Tosun, A., Keleş, I., Ayaşlığlu, E., Tosun, O., Orkun, S., 2006. Brucellar spondylodiscitis : A case report. Int. J. Clin. Pract. 60, 1502-1505.

Aygen, B., Doğanay, M., Sümerkan, B., Yıldız, O., Kayabaş, U., 2002. Clinical manifastations, complication and treatment of brucellosis: a retrospective evaluation of 480 patients. Med. Mal. Infect. 32, 485-493.

Bal, A., Gürçay, E., Ünlüsoy, D., Çınar, C., Çakcı, A., 2008. Brusellozda kas iskelet sistemi komplikasyonları. Trakya Univ. Tıp Fak. Derg. 25, $20-25$.

Batmaz, E., Edis, E.Ç., Çiftçi, A., Akkoyun, S., Hatipoğlu, O.N., Gençhallaç, H., 2007. Brusellozda akciğer tutulumu: Olgu Sunumu. Trakya Üniv. Tip Fak. Derg. 24, 70-73.

Buzgan, T., Karahocagil, M.K., Irmak, H., Baran, A.I., Karsen, H., Evirgen, O., Akdeniz, H., 2010. Clinical manifestations and complications in 1028 cases of brucellosis: a retrospective evaluation and review of the literature. Int. J. Infect. Dis. 14, 469-478.

Colmenero, J.D., Reguera, J.M., Fernandez-Nebro, A., Cabrera-Franquelo, F., 1991. Osteoarticular complications of brucellosis. Ann. Rheum. Dis. $50,23-26$.

Corbel, M.J., Beeching, N.J., 2010. Brucellosis. In:Kasper DL, Fauci AS (eds). Harrison's infection diseases. 17th ed. New York, McGraw-Hill, 547-551.

Doğanay, M., Meşe, E.A., 2008. Bruselloz. In: Topçu AW, Söyletir G, Doğanay M (editörler). Enfeksiyon Hastalıkları ve Mikrobiyolojisi. 3.bask1, İstanbul, Nobel Tip Kitabevleri, 897-909.

Dilmener, M., 1990. Brusellozun klinik prezantasyonları. Klinik Derg. 1, 23-25.

Franco, M.P., Mulder, M., Gilman, R.H., Smits, H.L., 2007. Human brucellosis. Lancet Infect. Dis. 7, 775-786.

Güneş, T., Alim, A., Kaya, S., Poyraz, Ö., 2009. Seroprevalence of brucellosis in high-risk groups in central Anatolia. Cumhuriyet Tip Derg. 31, $112-115$.

Gürsoy, B., Tekin-Koruk, S., Sirmatel, F., Karaağaç, L., 2008. Bruselloz: 140 olgunun değerlendirilmesi. Klinik Derg. 21, $101-104$.

Hatipoglu, C.A., Bilgin, G., Tulek, N., Kosar, U., 2005. Pulmonary involvement in brucellosis. J. Infection. 51, 116-119.

Kanterewicz, E., Sanmarti, R., Mellado, J.A., Euras, J.M., 1994. Pseudogout masking brucellar arthritis. Br. J. Rheumatol. 34, $294-295$.

Mert, A., Ozaras, R., Tabak, F., Bilir, M., Yilmaz, M., Kurt, C., Ongoren, S., Tanriverdi, M., Ozturk, R., 2003. The sensitivity and specificity of Brucella agglutination tests. Diagn. Microbiol. Infect. Dis. 46, 241-243.

Mousa, A.R.M., Elhag, K.M., Khogali, M., Marafie, A.A., 1988. The nature of human brucellosis in kuwait. Study of 379 cases. Rev. Infect. Dis. 10, 211-217.

Mili, N., Auckenthaler, R., Nicod, L.P., 1993. Chronic Brucella empyema. Chest. 103, 620-621.

Pappas, G., Bosilkovski, M., Akritidis, N., Mastora, M., Krteva, L., Tsianos, E., 2003. Brucellosis and the respiratory system. Clin. Infect. Dis. 37, 95-99.

Papiris, S.A., Maniati, M.A., Haritou, A., Constantopoulous, S.H., 1994. Brucella haemorrhagic pleural effusion. Eur. Respir. J. 7, $1369-1370$.

Park, K.W., Kim, D.G., Park, C.Y., Kim, H.L., Jang, S.J., Choi, Y.S., Park, M.Y., Song, H.J., Lee, S.H., 2007. Fatal systemic infection with multifocal liver and lung nodules caused by brucella abortus. Am. J. Trop. Med. Hyg. 77, 1120-1123.

Peker, E., Doğan, M., Akbayram, S., Bektaş, M.S., Öner, A.F., 2010. Brusellozda akciğer tutulumu. Selçuk Tıp Derg. 26, 57-59.

Sağlık Bakanlığı Temel Sağlık Hizmetleri Genel Müdürlüğü Bulaşıcı Hastalıkların İhbarı ve Bildirim Sistemi Standart Tanı, Sürveyans ve Laboraruvar Rehberi. 4. Bask1.Ankara 2005.

Sağlık Bakanlığı Temel Sağlık Hizmetleri Genel Müdürlüğü 2001 Y1lı İstatistik Yıllığı.

Sanford, J.P., 1997. Brucella pneumonia. Semin. Respir. Infect. 12, 24-27.

Sözen, T.H., 2002. Bruselloz. In: Topçu AW, Söyletir G, Doğanay M (eds). İnfeksiyon Hastalıkları ve Mikrobiyolojisi. 2.baskı, İstanbul, Nobel Tip Kitabevleri. 636-642.

Takahashi, H., Tanaka, S., Yoshida, K., Hoshino, H., Sasaki, H., Takahashi, K., 1996. An unusual case of brucellosis in Japan: difficulties in the differential diagnosis from pulmonary tuberculosis. Intern. Med. 35, 310-314.

Topçu, A.W., Söyletir, G., Doğanay, M., 1996. İnfeksiyon Hastalıkları. Ankara: Nobel Tıp Kitabevleri. 486-491.

Webb, W.A., 1966. Thoroughman JC Solitary Pulmonary Nodule Due to Brucella Suis. Dis. Chest. 49, 222-224.

Yüce, A., Çavuş, S.A., 2006. Türkiyede bruselloz; genel bakış. Klinik Derg. 19, 87-97.

Young, E.J., 2010. Brucella Species. In: Mandell GL, Bennett JE, Dolin R, eds. Mandell, Douglas and Bennett's, Principles and practice of infectious diseases. 7th ed, Philadelphia; Churchill Livingstone Elsevier. 2921-2925.

Zengi, A., Elmas, F., Tasbakan, M., Basoglu, O.K., Ozhan, M.H., 2006. Exudative pleural effusion due to brucellosis in a patient with chronic obstructive pulmonary disease. Trop. Doct. 36, 253-254. 